\title{
REVIEW
}

\section{Holocene mammal extinctions in the Carpathian Basin: a review}

Attila NÉMETH* MTA-MTM-ELTE Research Group for Paleontology, Ludovika tér 2., Budapest, H-1083 Hungary.E-mail: attila.valhor@gmail.com

Annamária BÁRÁNY Hungarian National Museum, Múzeum körút 14-16., Budapest, H1088 Hungary. E-mail: baranya@hnm.hu

Gábor CSORBA Hungarian Natural History Museum, Baross u. 13., Budapest, H-1088 Hungary.E-mail: csorba@nhmus.hu

Enikö MAGYARI MTA-MTM-ELTE Research Group for Paleontology, Pázmány P. sétány 1/C, Budapest, H-1117 Hungary.E-mail:emagyari@caesar.elte.hu

Piroska PAZONYI MTA-MTM-ELTE Research Group for Paleontology, Ludovika tér 2., Budapest, H-1083 Hungary.E-mail: pazonyi@nhmus.hu

József PÁLFY MTA-MTM-ELTE Research Group for Paleontology and Eötvös Loránd University, Department of Physical and Applied Geology, Pázmány P. sétány 1/C, Budapest, H-1117 Hungary.E-mail: palfy@nhmus.hu

\section{ABSTRACT}

1. Mammals are a key target group for conservation biology. Insights into the patterns and timing of and driving forces behind their past extinctions can help us to understand their present situation, and to predict and mitigate their future biodiversity loss. Much research has been focused on the intensely debated megafaunal extinctions at the Pleistocene- 
Holocene transition, whereas the Holocene mammal extinctions have remained less studied.

2. Here we consider the Holocene extinctions of mammal taxa in the Carpathian Basin, a distinctive and biogeographically well-constrained predominantly lowland region in Central Europe. For the first time, we combine data from palaeontological, archaeozoological and historical sources for a comprehensive analysis.

3. A total of 11 mammal species, including steppe-dwelling rodents, large carnivores and herbivores, disappeared from the Carpathian Basin during the Holocene. The extinctions are interpreted in the framework of changing habitats and ecosystems, as grasslands and open forests vanished at the westernmost limits of the Eurasian steppe.

4. The temporal distribution of extinctions is non-random; most taxon range terminations are concentrated around two discrete events. Members of the steppe community disappeared between 5000 and 4000 years before present, around the Copper Age-Bronze Age transition. Large herbivores that found refugia in the forests vanished later, between the $16^{\text {th }}$ and $18^{\text {th }}$ centuries AD (anno Domini). The steppe and forest steppe ecosystems of the Carpathian Basin suffered a considerable loss in their mammalian fauna during the Holocene, which has significant implications for conservation efforts for the existing similar dry, open habitats in western Eurasia.

5. Further research and better age constraints are needed to establish the causes of extinctions more firmly, but the lack of synchronous and severe climate and vegetation changes and the coincidence with transformations in human prehistory and history suggest the prime role of anthropogenic disturbance. We conclude that there were two waves of Holocene mammal extinctions of megafaunal character in the Carpathian Basin.

Keywords: anthropogenic disturbance, Carpathian Basin, extinction, Holocene, megafauna 
Running title: Mammal extinctions in the Carpathian Basin

Submitted: 22 October 2015

Returned for revision: 9 December 2015

Revision accepted: 12 April 2016

Editor: KH/DR

*Correspondence author

\section{INTRODUCTION}

Species extinctions and changes in the structure of mammalian communities are fundamentally natural processes (Raup 1994). Such changes occurred at the PleistoceneHolocene transition, when climate and ecosystems in Europe were transformed from a cold environment to the present-day moderate one (Altuna 1999). These changes in most regions of Europe were characterised by local extinctions or faunal replacements resulting from largescale biogeographical movements (Hewitt 2002, Schmitt 2007). Remarkably similar local or global extinctions also occurred later in the Holocene (Kosintcev 1999, de Bruyn et al. 2011). This epoch was crucial to the development of the recent mammalian fauna of each European region, and was characterised by significant differences in the species composition of successive stages that witnessed successive losses of mammal species (Bartosiewicz 1999a). These extinctions are ascribed to climatic oscillations (Kosintcev 1999), succession of the communities and ecosystems (Benecke 1999), direct human impact (Ervynck et al. 1999, Vigne 1999) or to combinations of these factors (Pushkina \& Raia 2008).

Several studies have dealt with the postglacial development of the mammalian fauna of different regions of Europe (e.g. Altuna 1999, Benecke 1999, Ponomarev et al. 2013). From both archaeological and palaeontological excavations, a large number of Holocene mammal species' occurrences have been recorded. However, reports of the excavated osteological 
material are typically scattered in diverse sources, published according to the ethnological and cultural context. A synthesis is further hampered by the highly variable quality of the dating. Until now, no interdisciplinary studies have been carried out on the changes in mammalian communities of the Carpathian Basin, a topographically well-defined unit in Central Europe. Only the subfossil mammalian records have been evaluated, separately for the individual countries in this geographical region (e.g. Hungary), and all of these studies dealt with either the palaeontological (Kordos 1981) or the archaeozoological records (Vörös 1987a, Bartosiewicz 1999a).

Here we review the changes in the composition and structure of mammalian communities of the Carpathian Basin that occurred during the Holocene. Using an interdisciplinary approach, we amalgamate for the first time the available subfossil records, from both archaeozoological and palaeontological sources, with the relevant historical records. From the temporal and spatial distribution of locally extinct species, a pattern of two distinct extinction waves emerges. These waves of extinctions are interpreted to be of megafaunal type and may be related to periods of change in human prehistory and history.

\section{METHODS}

\section{Study area and scope}

Our study area is the Carpathian (or Pannonian) Basin, a well-defined geomorphological and biogeographical unit in Europe (Varga 1995, Moores \& Fairbridge 1997). Belonging to the drainage basin of the River Danube and situated in Central Europe, it is almost entirely surrounded by the Alps, Carpathian Mountains and Dinaric Alps, making it one of the most geographically isolated regions of Europe. The high degree of isolation has an important effect on the biota of the Carpathian Basin; it harbours high natural biodiversity and is rich in endemic taxa (Varga 1995). Therefore, the Carpathian Basin is an excellent natural laboratory 
for investigating the role of natural and human-driven processes in the development of and structural changes in mammalian communities throughout the Holocene.

The scope of this study is restricted to the Holocene, which is now formally defined to start at 11700 calendar years before present (Walker et al. 2009). Changes in mammalian communities are considered until $1800 \mathrm{AD}$, the date commonly (but not equivocally) suggested as the beginning of the Anthropocene (Steffen et al. 2011). The Anthropocene is informally used to describe the most recent part of Earth's history, when humans become geological and biological agents for planetary change (Crutzen 2002, Dirzo et al. 2014). However, here we avoid taking a stand in the debate about the formal introduction of the term Anthropocene. Assessing the impact of the epoch informally called the Anthropocene on mammals (Dirzo et al. 2014) is beyond the scope of this study.

\section{The subfossil record and its dating}

Data used in this study were gathered from both published and unpublished palaeontological and archaeozoological reports pertaining to the Holocene from Austria, Hungary, Romania, Slovakia and the northern states of the former Yugoslavia (Croatia, Serbia and Slovenia), which share the territory of the Carpathian Basin.

In most cases, records of each species were dated on the basis of their assignment to a sedimentary layer or archaeological culture, assigned to climatic phases (see below). The material originating from palaeontological reports, especially those from existing databases, was critically reviewed previously (Pazonyi 2011). Precise temporal assignment of a record is best achieved by ${ }^{14} \mathrm{C}$ dating of single bones. Besides published ${ }^{14} \mathrm{C}$ dates, some additional, unpublished dates are also used. Nevertheless, not all records could be assigned directly to a climatic phase, as in some cases they were dated inappropriately or inaccurately. In many of

these cases, records were dated to cultural epoch and were included in this review. To classify 
and date the cultural epochs, the chronology of Visy (2003), widely accepted by

archaeologists in the Carpathian Basin, was used; this allows any cultural epoch to be referred to a climatic phase. Correlation of chronostratigraphic units, climatic phases and cultural epochs is shown in Fig. 1.

\section{Chronological terminology and locality mapping}

The terminology of climatic phases used here follows Sommer and Benecke (2006) and Sommer et al. (2014). The climatic phases are defined by pollen zones with age estimates given by Street et al. (2002). Stratigraphical subdivision of the Holocene to Early, Middle and Late Holocene sub-epochs follows the suggestion of Walker et al. (2012).

All the sites studied by palaeontologists or archaeologists were mapped temporally and spatially, and displayed sequentially on digital maps using Geographical Information System methods (Fig. 2). Each find is a point on a map, representing the remains of at least one individual mammal from one site.

\section{RESULTS}

The rich Holocene subfossil records (Fig. 2) reveal that 11 mammal species, representing nearly $10 \%$ of the whole mammalian fauna, disappeared from the Carpathian Basin during the Holocene, and are not represented in its present-day fauna (Fig. 1).

\section{Steppe pika Ochotona pusilla}

During the Pleistocene, the steppe pika occupied vast areas in Eurasia (Fisher \& Yalden 2004), but the postglacial re-establishment of forests restricted the range of the species (Erbajeva 2008). In the Carpathian Basin, the steppe pika was a common member of the Late Pleistocene fauna and it survived into the Holocene (Kordos 1981, Pazonyi 2011). 
Bone remains of the species were found exclusively in cave sediments (Kordos 1978, 1981) from 25 sites or layers, from the earliest Holocene until the very end of the Copper Age (Pazonyi 2011).

On the basis of fossil remains, molar structure and karyological traits, the steppe pika is often considered to be a relict from the Late Pliocene, a view supported both by mtDNA sequence data (Niu et al. 2004) and by its continuous existence in the Carpathian Basin (Pazonyi 2011).

Kordos $(1978,1981)$ regarded the steppe pika as a cold-adapted late survivor of the Pleistocene mammoth steppe fauna, suggested that its occurrence in mountainous localities resulted from a shift of habitats forced by a cooling climate, and linked the pika's extinction from the Carpathian Basin to climatic changes. However, the steppe pika is the only species of the family Ochotonidae that avoids mountainous habitats and exists only on flatlands and piedmont grasslands (Erbajeva 2008, Smith \& Johnston 2008). We consider it unlikely that the steppe pika moved to a mountainous environment in the Carpathian Basin during the Holocene. Pika remains from the cave sediments are the result of accumulation from owl pellets (Kordos 1981), so it is plausible that steppe pikas originally lived and fell prey to owls in steppes, and only their remains were transported to caves by owls. This view is further supported by the present distribution of the steppe pika in the continental steppes of Central Asia, where aridity exerts more control on its distribution than cool climate (Smith \& Johnston 2008). The geographical range of this species contracted significantly in historical times (Smirnov 1993, Smith 1994), and the steppe pika is regarded to be an excellent indicator of the general health of steppe ecosystems (Smith \& Johnston 2008). The species strictly avoids human disturbance (Smith 1994); this could account for its absence from the archaeozoological record. 


\section{Narrow-headed vole Microtus gregalis}

In the Late Pleistocene, the narrow-headed vole was widely distributed over huge territories of Eurasia from Western Europe to East Siberia (Abramson et al. 2006), and was also common in the Carpathian Basin (Kordos 1981, Pazonyi 2011). Due to the formation of a wide taiga zone during the Late Pleistocene-Holocene transition, the species' range became extremely fragmented in the remaining northern (tundra) and southern (steppe and mountain) segments (Abramson et al. 2006, Batsaikhan et al. 2008). Although most European populations of the narrow-headed vole went extinct at the Pleistocene-Holocene boundary, the species survived in the Carpathian Basin until the end of the Middle Holocene (Kordos 1981, Pazonyi 2011).

The spatial and temporal distribution patterns of subfossil narrow-headed vole remains are very similar to those of the steppe pika. All narrow-headed vole finds are from cave sediments (Kordos 1978, 1981); the age range of the 23 sites or layers spans from the Early Holocene until the Late Copper Age (Pazonyi 2011).

The fragmented range and the morphological variation between the recent populations raise the probability that the narrow-headed vole represents a complex of closely related species (Batsaikhan et al. 2008). A molecular biological study showed that all isolated geographic populations form highly supported monophyletic groups, though genetic differentiation between the northern and southern populations is significantly smaller than between samples from the south-western and Transbaikal populations (Abramson et al. 2006).

Populations of the narrow-headed vole that formerly existed in the Carpathian Basin were probably identical to the recent south-western Asian and Central Asian populations. It is also possible that during the Early and Middle Holocene the distribution of these populations were geographically continuous. The remarkably similar spatial and temporal distribution 
patterns of the steppe pika and the narrow-headed vole suggest that the same mechanism was responsible for the extinction of both species.

\section{Bobak marmot Marmota bobak}

Marmots were present in the Carpathian Basin during the Pleistocene. The remains were identified by different authors as various species: Marmota marmota (Mottl 1936), Marmota primigenia (Kretzoi 1954) and Marmota bobak (Jánossy 1976). Although taxonomy remains controversial, it is possible that different marmot species inhabited the Carpathian Basin at the different stages of the Pleistocene. The bobak marmot is known from Hungary from the late Middle and Late Pleistocene (Kretzoi 1954, Jánossy 1976) and from Transylvania from the Late Pleistocene (Koch 1888).

From a Neolithic archaeological locality at Legii Hill, at the eastern edge of the Great Hungarian Plain, a single find of a bobak marmot was reported (Jurcsák 1974, Venczel 2000). This subfossil record indicates that bobak marmots survived the Pleistocene-Holocene transition in the Carpathian Basin.

\section{Lion Panthera leo}

In the Carpathian Basin, lion remains of Holocene age are known only from the territory of Hungary, from eight localities. Findings are summarised by Vörös (1983), and recent excavations have added another four localities to the list (Vörös 2012, Daróczi-Szabó \& Savanyú 2013, Kovács Zs. unpub. data, Bárány A. unpub. data). The wide geographic distribution of the localities indicates that lions were widely distributed in the central part of the Carpathian Basin.

Although morphological differences between the Pleistocene cave lion Panthera leo spelaea and the recent lion of the Holocene are negligible (Sommer \& Benecke 2006, 
Bartosiewicz 2009), molecular analyses indicate that the cave lion and recent African and Asian lion lineages became isolated from one another about 600000 years ago (Burger et al. 2004). Cave lions became extinct without mitochondrial descendants (Burger et al. 2004), but detailed data on the zoogeographical changeover of lion types in Europe during the Pleistocene-Holocene transition have been lacking. The youngest fossil remains of cave lions from Hungary are dated between 20000 and 18000 BC (before Christ; Vörös 1987a), suggesting that the cave lion had gone extinct in the Late Pleistocene much earlier than modern lions appeared in the Holocene (Vörös 1983, 1987a).

According to Bartosiewicz (1999a), canines from the Late Neolithic and Middle Copper Age do not reflect the distribution of living lions, but instead are attributable to the longdistance trade of high-status items. However, all other lion findings, represented by various skeletal remains, strongly suggest that the species was hunted locally (Vörös 1983, Bartosiewicz 1999a). Most of the lion records are dated to the Middle and Late Copper Age, and no Bronze Age or younger lion remains are known from the Carpathian Basin.

\section{Leopard Panthera pardus}

The leopard is well-known and widely distributed in the Late Pleistocene in Europe, but its occurrence and distribution during the Holocene remains uncertain (Sommer \& Benecke 2006). Aside from a Mesolithic specimen from northern Spain (Altuna 1967) and a subfossil record from the Colosseum of Rome (De Grossi Mazzorin 1995), Holocene leopard remains are known only from the Ponto-Mediterranean and Balkan regions (Symeonidis et al. 1980, Zhuralev 1999).

The Holocene distribution patterns of leopards and lions are remarkably similar to each other (Sommer \& Benecke 2006), in agreement with the present day distribution of the two big cats: where lions occur (Bauer et al. 2012) one can find leopards as well (Henschel et al. 
2008). However, the geographical range of the leopard is significantly larger than that of the lion; the leopard has more northerly occurrences, and the species has the widest habitat tolerance of all Old World felids (Henschel et al. 2008). Assuming that the distribution pattern, ecology and biogeography of the two species were similar during the entire Holocene, the leopard's range would have included the Carpathian Basin via the Balkans. Although the only record of the leopard dated to the Late Middle Ages probably represents a piece of imported precious fur (Bartosiewicz 2001), based on ecological and biogeographical grounds we assume that the species was part of the natural mammalian fauna of the Carpathian Basin. In Europe, remains of big cats were not found until the end of the 1920s (Gromova 1928), and they are generally extremely rare in the archaeozoological record (Sommer \& Benecke 2006). Moreover, remains of large carnivores are quite often misidentified (Vörös 1983, Bartosiewicz 2001).

\section{Wild horse Equus ferus}

The wild horse was one of the most common species in the Late Pleistocene ungulate fauna of Eurasia (Kahlke 1999, Sommer et al. 2011). According to Guthrie (2003), after the disappearance of the mammoth steppe biome at the Pleistocene-Holocene transition, the environment became suboptimal for wild horses. Some authors have assumed that the wild horse became extinct in Europe at the beginning of the Holocene and that all younger records are the results of erroneous dating (e.g. von Koenigswald 2002). However, since more than 200 Early and Middle Holocene sites throughout Europe have yielded wild horse remains (Sommer et al. 2011), this assumption seems untenable. Vörös (1994) conclusively proved that the wild horse was a member of the native fauna of the Carpathian Basin during the Early and Middle Holocene. 
Although some uncertainties remain due to the problems of morphological distinction of wild and domesticated horses, wild horse finds are known from at least 37 Holocene localities in the Carpathian Basin, from the territory of Austria, Hungary, Romania, Serbia and Slovakia (Vörös 1981, 1994, Bãlãşescu et al. 2003, Vörös 2005, Schmitzberger 2009).

The number of Late Pleistocene and Holocene wild horse taxa and their phylogenetic relationships are debated. Some researchers believe that only a single species of horse existed throughout Eurasia, and that all the known nominal taxa should be regarded as subspecies or mere regional varieties (Groves 1994, Grubb 2005). Others believe that different species of wild horses lived contemporarily (Sokolov 1967, Groves \& Grubb 2011), and that the European wild horse Equus ferus and the Asian wild horse Equus przewalskii represent distinct species. Horses of the Late Pleistocene and Holocene were diverse in terms of both skeletal morphology (Vörös 1981, Forsten 1993, Eisenmann \& Baylac 2000) and genetics (Ludwig et al. 2009, Pruvost et al. 2011). Here we follow the taxonomic opinion that all Holocene horses in Europe represent a single species, Equus ferus.

Most wild horse remains are Neolithic in age, but timing their extinction is hampered by difficulties in the identification of Copper Age horses. Previously, all Hungarian horse remains from the Copper Age were identified as the domesticated horse (e.g. Bökönyi 1971a, 1974), mostly for historical reasons. However, recent research suggests that wild horses were first domesticated in Kazakhstan c. 5500 calendar years before present (Outram et al. 2009), and that the first domestic horses appeared in Europe only in the Bronze Age (Ludwig et al. 2009). No domesticated horse remains have been found in Copper Age archaeological material in Europe (Pruvost et al. 2011), and the abundance of horse bones in Copper Age settlements is low, and similar to that of rare wild animals (Bartosiewicz 1999a). A combination of climatic and anthropogenic effects was suggested to account for the demise of wild horse (Guthrie 2003, Lorenzen et al. 2011, Sommer et al. 2011). However, records from 
the Carpathian Basin do not support this scenario, as the abundance of horse remains remained steady throughout successive changes of vegetation. In this region, the effect of human activity appears to be more significant, and we assume that the extinction of wild horse populations from the Carpathian Basin happened from 5000 to 4000 before present, when people of the Yamnaya culture settled in Europe (Allentoft et al. 2015). Wild horses probably became extinct in the Carpathian Basin only around the Copper Age - Bronze Age transition or during the Bronze Age, when large herds of domesticated horses first appeared in the region (Bökönyi 1971a).

\section{Asiatic wild ass Equus hemionus}

Remains referred to as European wild ass Equus hyndruntinus are common at numerous Pleistocene and Holocene sites across Europe. Holocene finds of wild asses in the Carpathian Basin are known from a total of 22 sites in Austria, Hungary, Romania, Serbia and Slovakia (Vörös 1981, 1994, 2005, Schmitzberger 2009). The majority of the localities are in the central part of the Carpathian Basin.

The taxonomy of the species was controversial until recently. Equus hydruntinus shares morphological traits with numerous other species of Old World Pleistocene equids (Forsten 1999) and it is variably classified as a zebra (Davis 1980), an ass (Gromova 1949), or a stenonid (Forsten 1999). Detailed investigation of two nearly complete crania revealed that Equus hydruntinus is more closely related to the Asiatic wild ass Equus hemionus than to any other equid (Burke et al. 2003). Analyses of the mtDNA further support the proximity of Equus hydruntinus and Equus hemionus, and now it seems likely that Equus hydruntinus is conspecific with Equus hemionus (Orlando et al. 2006, Geigl \& Grange 2012). Based on an osteologic, stratigraphic and zoogeographic survey of wild ass remains in Hungary and Serbia, a similar conclusion was reached, and the bones were identified as a local variant of 
Equus hemionus (Vörös 1981). Wild asses of the region probably represent a distinct European subspecies, or one that is endemic to the Carpathian Basin, as proposed by Kretzoi (1968).

Bones of wild asses occur in the Carpathian Basin from the beginning of the Holocene until the end of the Neolithic (Vörös 1981). A single record from the western edge of the region indicates that the species may have survived in the Carpathian Basin until the Late Copper Age (Schmitzberger 2009).

\section{European fallow deer Dama dama}

The postglacial distribution of the European fallow deer remains uncertain (Sykes et al. 2013), but Turkey and Southern Europe are considered glacial refugia for the species (Masseti \& Mertzanidou 2008).

The genus was present in the Carpathian Basin during the last interglacial (Pazonyi et al. 2014). The earliest Holocene record of the species is from the Late Mesolithic, near the southern edge of the region. Originally identified as an extremely large roe deer Capreolus capreolus buck (Bökönyi 1978), it was later revised as a fallow deer (Vörös 2005). Further remains were identified from the Middle and Late Neolithic, Middle Copper Age and Early Bronze Age from the territory of Hungary, Romania and Serbia (Vörös 1987b, El Susi 1991, Becker 1997, 1998, Schwartz 1998, Becker 1999, Haimovici 2007). After a long hiatus, the fallow deer appears again only in the Roman Age and later in the Middle Ages (Vörös 1987a).

Because of their large size, the Middle Copper Age bones were first identified as Persian fallow deer Dama mesopotamica (Vörös 1987b), but biogeographical considerations suggest that this identification is erroneous (Rabiei \& Saltz 2011). These bones are clearly larger than the Roman Age and Medieval remains, and exceed the size of recent European fallow deer as well (Németh, Bárány \& Csorba, unpublished data), allowing speculation that 
the specimen belonged to a young red deer Cervus elaphus rather than to a fallow deer (Bartosiewicz 1999a). However, size variations are both geographically and temporally controlled. Morphological comparisons proved that fallow deer of the Neolithic and Bronze Age were substantially larger than the recent European population within the same area (Bökönyi 1971b, Fabiš 2003), and that a definite size reduction occurred in the Roman Age (Sykes et al. 2013), suggesting that Romans not only extensively introduced, but also slightly domesticated the species (Masseti \& Mertzanidou 2008, Davis \& Mackinnon 2009).

Based on the large number of sites yielding fallow deer remains, the wide geographic range of the species and the long age range spanning different human cultures from the Mesolithic to Bronze Age, it is unlikely that the natural distribution area of the species never reached the central part of the Carpathian region (Becker 1999), and that all these numerous finds would be linked to exotic import.

A similar general trend was also observed in the Carpathian Basin, where the native fallow deer population consisting of large individuals was succeeded by one with smaller individuals in the Roman Age. The two populations may never have been contemporaries in the region, as the one with larger body size became extinct during the Bronze Age, in the same period when the species suffered a dramatic decline in its entire European distribution area (Becker 1998).

\section{Eurasian elk Alces alces}

The fossil record reveals that the Eurasian elk was common in the Carpathian Basin during the Middle and Late Pleistocene (Biller 2013). The species vanished from the central part of the Carpathian Basin during the latest Pleistocene, but possibly survived into the Holocene in the mountainous periphery of the region (Vörös 2000, Sommer \& Nadachowski 2006). 
At least six records are known from the territory of Hungary and Romania from the Middle Copper Age, the Early and Middle Bronze Age and the Roman Age (Topál \& Vörös 1984, Vörös 1987a, Biller 2013). Another two occurrences from Hungary and Slovakia were dated as 'prehistoric' (Vörös 2000) and 14 more from Romania are regarded as 'postglacial' (Czier \& Jurcsák 1987); all of these could be interpreted as Holocene records. Elk remains were found at 12 sites in the Sava River valley, at the south-western border of the Carpathian Basin (these localities are not shown in Fig. 2I; Vörös 2000). All of them were considered Holocene by Rakovec (1956), but it is likely that most of these sites are in fact Late Pleistocene (Malez 1972).

Hungarian archaeozoologists traditionally explain the scarcity of the local elk record by intermittent colonisation (Vörös 2003, 2013) or by the existence of vagrant individuals (Topál \& Vörös 1984, Biller 2013). Their opinion is based on the view that the southern limit of the natural distribution of elk was located much farther north during the Holocene (Biller 2013). However, in the Early Holocene, the elk's geographical range extended from the Pyrenees to Denmark and from Great Britain to Eastern Europe, and included Central Europe as well (Schmölcke \& Zachos 2005). The southern limit of the elk's range in the Balkan was at $45^{\circ} \mathrm{N}$ latitude (Haimovici 2007), farther south than the southern part of the Carpathian Basin. Therefore, the elk was probably permanently present in the Carpathian Basin during the Holocene, until its local extinction.

Although no archaeozoological records are known, written sources of information from the Middle Ages frequently mention the species in the region. Albertus Magnus, in his work titled De Animalibus (About the animals; 1258-1262), wrote that elk were well-known animals in the territory of the Hungarian Kingdom, and that many of them lived in the forests of the country. Elk was mentioned as a royal game species in mountainous Transylvania in the $16^{\text {th }}$ century AD (Bartosiewicz et al. 2010). On the basis of a comprehensive survey of 
literature, historical and linguistic data, Szalay (1916) concluded that the elk went extinct during the $15^{\text {th }}$ century in the western part of the Carpathian Basin and in the $17^{\text {th }}$ century in Transylvania. However, questionable historic accounts of the elk's occurrence in western Hungary are given up to the $18^{\text {th }}$ century, e.g. by Turóczy from 1729 AD and by Fashing from 1743 AD (Szalay 1916).

\section{Aurochs Bos primigenius}

The aurochs was present in the Pleistocene fauna of the Carpathian Basin, primarily during the warmer, interglacial periods (Jánossy \& Vörös 1981, Vörös 1987c, Pazonyi 2011). Its Holocene remains are known from the Mesolithic to the Late Middle Ages from almost every region of the Carpathian Basin.

The species is generally confined to woodland habitats (van Vuure 2005), although subfossil records and isotope analyses indicate that it previously used open habitats throughout Europe (Hall 2008, Drucker \& Bocherens 2009).

In the Carpathian Basin, the aurochs is one of the most common species in Early Holocene archaeozoological records. Neolithic and Copper Age assemblages are characterised by high percentages of aurochs bones, whereas by the Bronze Age the percentage of remains attributed to aurochs fell below 5\%. Archaeological sites from the Iron Age, Roman Age and Migratory Period yielded only a small number of aurochs bones (Bökönyi 1963, Bartosiewicz 1999b). From the Middle Ages, only a few sites yielded aurochs remains (Bökönyi 1974). According to Vörös (1985), the aurochs became extinct by the $9^{\text {th }}$ $11^{\text {th }}$ century $\mathrm{AD}$ in the Carpathian Basin (at least in the territory of present-day Hungary), and all Late Medieval and younger remains, artefacts (including drinking horns), and illustrations represent long-horned large domestic cattle, rather than aurochs. However, in the Romanian part of the Carpathian Basin, four localities yielded aurochs remains dated to the $11-13^{\text {th }}$ 
century AD (Bejenaru et al. 2013). A single site from Hungary is also known from this period with aurochs bones (Bökönyi 1974). From the north-western edge of Transylvania, aurochs remains dated to the $14^{\text {th }}-15^{\text {th }}$ century AD are reported (El Susi 2000). This is the youngest known occurrence of the species from the Carpathian Basin. Bejenaru et al. (2013) concluded that aurochs were extirpated from Moldavia and Transylvania around the $16-17^{\text {th }}$ century AD, almost simultaneously with the extinction of the well-known population in Central Poland.

\section{European bison Bison bonasus}

Holocene subfossil remains of the European bison in the Carpathian Basin are known from Austria, Hungary, Romania and Slovakia. Beside the skeletal remains, many written sources, mainly from the Middle Ages, document the presence of the species (Vörös 2013). The distribution of the bison included almost every region of the Carpathian Basin, from plains to hilly terrains. The earliest finds are dated as Late Mesolithic. Further remains are known from the Neolithic, Bronze Age, Iron Age, Roman Age and from the Middle Ages to the Modern Age.

The earliest records of the European bison are from Early Holocene sites in NorthernCentral Europe and Southern Scandinavia, and the ancestry and origin of the species are still debated (Verkaar et al. 2004, Benecke 2005). Two subspecies are recognised: the lowland bison Bison bonasus bonasus, known from the northern plains of Europe (Poland, Belarus) and Bison bonasus caucasicus, native to the Caucasus region (Krasińka \& Krasińki 2013). Based on differences in size and morphology, subfossil remains from the Carpathian Basin were described as a distinct subspecies, Bison bonasus hungarorum (Kretzoi 1946). Although this subspecies is less well-known, it has been increasingly widely accepted (Flerov 1979, Krasinska \& Krasinski 2013, Vlasakker 2014). 
Kerley et al. (2012) suggest that woodlands are suboptimal habitats for the European bison, and only the human influence drove this species there; its original habitat is the more open, grassy park forests or forest steppe. In the Carpathian Basin, the bison was forced from the plains to the hilly regions in the $14^{\text {th }}$ century AD (Hankó 1933), and by the Late Middle Ages, the Hungarian subspecies was totally extinct (Vörös 2013). The bison that lived in Transylvania from the $17^{\text {th }}$ century are thought to have originated from captive stock and represent the lowland subspecies (Vörös 2013). However, an illustration of bison captured in Transylvania from 1732 AD depicts specimens with morphology different from the lowland bison, and it is possible that these individuals represent the Hungarian subspecies. However, it is also plausible that the subspecies had suffered introgression from other subspecies by the $17^{\text {th }}$ century. A subfossil find dated to the $15^{\text {th }}-17^{\text {th }}$ century from southwestern Hungary indicates that bison may have also survived in the western Carpathian Basin till the end of the Medieval period (Bökönyi 1974).

\section{DISCUSSION}

\section{Species, ecosystems and conservation aspects}

Vast territories in the Carpathian Basin were once covered by open landscapes: dry grasslands (steppe) and forest steppe (Illyés et al. 2007, Magyari et al. 2010). Many of the extinct mammal species, such as the steppe pika, the narrow-headed vole, the bobak marmot, the wild ass and the wild horse, are undoubtedly linked to these habitats. The fallow deer presumably also lived in dry, open, forest-steppe ecosystems, similar to its Mediterranean woodland habitats (Masseti \& Mertzanidou 2008, Rabiei \& Saltz 2011). The lion and the panther, other southern elements of the fauna, may well be connected to these ecosystems too. Thus, most of the extinct species of the Carpathian Basin, 8 out of 11, once inhabited dry, open habitats. Their extinction caused a major transformation in the mammalian community 
and undermined the stability of the whole ecosystem, to the extent that some consequences are felt through to the present times.

Marmots and pikas are keystone species in their respective ecosystems (Lai \& Smith 2003, Murdoch et al. 2009). In Kazakhstan and Mongolia, where these small steppe mammals or their close relatives still exist, they play an important role in the survival of threatened raptors and small carnivores (Lai \& Smith 2003, Katzner et al. 2005). These small mammals also play a crucial role in maintaining a diverse plant community through the disturbance they cause. Activity of the steppe pika is key to the seed dispersal of the dwarf Russian almond Amygdalus nana (Bölöni \& Horváth 2012), and its importance was also considered for other threatened or rare species (A. Molnár, pers. comm.).

The importance of large herbivores in grassland ecosystems is clear, and their role was filled by large domestic animals for a long time in the Carpathian Basin. However, after the extensive land-use change and the regression of pastoralism in most of the region during the $20^{\text {th }}$ century, the management of grazing became a crucial issue for protected grasslands (Báldi et al. 2005, Horváth et al. 2009). The Carpathian Basin is located at the western edge of the Great Eurasian steppe belt, and the grasslands of this region are much more isolated by the surrounding mountain ranges than those in any other part of the otherwise contiguous Eurasian steppe belt (Illyés et al. 2007). These two reasons together have made the Pannonian grassland ecosystems highly vulnerable, meaning that even a small perturbation could lead to significant extinction.

The aurochs and the European bison, usually linked to temperate deciduous forests, are thought to be "refugee species" that originally inhabited mosaic landscapes of grassland and woodland habitats (Kerley et al. 2012). This is concordant with the wood-pasture hypothesis (Vera 2000, Vera et al. 2006): that the presence of large herbivores maintained an open landscape composed of a mosaic of groves, closed-canopy woodlands, open parkland and 
regenerating scrub in the primeval Holocene woodlands of the European lowlands. The role of large herbivores in woodland ecosystems is also an important issue and a long-term source of dispute and disagreement that influences current forest conservation and management policies (Birks 2005).

\section{Pattern and causes of extinctions}

The temporal distribution of species' extinctions is remarkable: instead of being evenly and randomly distributed throughout the Holocene, they appear to be concentrated during two discrete events of short duration. Furthermore, each of these events is connected to the fate of an ecosystem. Most of the mammal species' extinctions in the steppe and forest-steppe ecosystems took place between 5000 and 4000 before present, around the Copper Age-Bronze Age transition. Later, between the $16^{\text {th }}$ and $18^{\text {th }}$ centuries AD, another extinction event occurred, when all the large herbivores that had found refugia in the forests vanished.

Many common features are noted among the mammal species that suffered synchronous regional extinctions in the Carpathian Basin. Most of them are characterised by large body size. All of the largest herbivores of the Carpathian Basin, and all the large carnivores related to grasslands, died out. In addition, all the vulnerable species, such as the elements of the southern mammalian fauna living at the northern limit of their distribution, and those small mammals that are least able to tolerate human disturbance, e.g. the steppe pika (Smith 1994), became extinct. Taken together, these features are typical of megafauna extinction events, such as the ones that occurred during the latest Pleistocene in continental ecosystems and during the Holocene on islands (Martin \& Steadman 1999, Wroe et al. 2004). Human 'overkill' is regarded as the main factor in, or at least as a partial reason for, those megafauna extinctions (Alroy 2001, Wroe et al. 2004, Turvey \& Fritz 2011). According to the pollenbased reconstructions of climatic oscillations and vegetation changes in the Carpathian Basin 
during the Holocene (Feurdean et al. 2015, Magyari et al. 2010), no major climatic or vegetation changes coincide with the extinction events identified here. This raises the possibility of direct human impact as the key factor, a hypothesis explored further by our ongoing research.

\section{ACKNOWLEDGEMENTS}

L. Bartosiewicz and I. Vörös are thanked for fruitful discussions and sharing their vast knowledge on archaeozoology of the Carpathian Basin. Comments by two anonymous reviewers helped improve the manuscript. The first author was supported by an MTA Postdoctoral Fellowship. This is MTA-MTM-ELTE Paleo Contribution No. 216.

\section{REFERENCES}

Abramson NI, Kostygov AYU, Gambaryan NG (2006) Phylogeography of narrow-skulled vole (Microtus gregalis, Cricetidae, Rodentia) inferred from the variation of mithocondrial cyt $\mathrm{b}$ and a number of nuclear genes. Hystrix - the Italian Journal of Mammalogy 17 supp: 155-156.

Allentoft ME, Sikora M, Sjörgen KG, Rasmussen S, Rasmussen M, Stenderup J et al. (2015) Population genomics of Bronze Age Eurasia. Nature 522: 167-172.

Alroy J (2001) A multispecies overkill simulation of the end-Pleistocene megafaunal mass extinction. Science 292: 1893-1896.

Altuna J (1967) Fauna de mamiferos del yacimiento prehistórico de Marizulo (Urnieta, Guipúzcoa). Munibe (Antropologia-Arkeologia) 19: 371-298.

Altuna J (1999) Mammal changes between the Dryas and the Holocene in Northern Spain. In: Benecke N (ed) The Holocene History of the European Vertebrate Fauna, 1-8. Archäologie in Eurasien, 6. Verlag Marie Leidorf, Rahden, Germany. 
Bãlãşescu A, Udrescu M, Radu V, Popovici D (2003) Archéozoologie en Roumanie: Corpus de Données. Musée National d'Historie de Roumanie Bibliotheque du Musée National Série Recherches Pluridisciplinaires, 5. Cetatea de Scaun, Târgovişte, Romania.

Báldi A, Batáry P, Erdős S (2005) Effects of grazing intensity on bird assemblages and populations of Hungarian grasslands. Agriculture, Ecosystems and Environment 108: 251-263.

Bartosiewicz L (1999a) The emergence of Holocene faunas in the Carpathian Basin: a review In: Benecke N (ed) The Holocene History of the European Vertebrate Fauna, 73-90. Archäologie in Eurasien, 6. Verlag Marie Leidorf, Rahden, Germany.

Bartosiewicz L (1999b) Aurochs (Bos primigenius Bojanus, 1827) in the Holocene of Hungary. In: Weniger G-C (ed) Archäologie und Biologie des Auerochsen. Neanderthal Museum, Wissenschafliche Schriften 1: 103-117.

Bartosiewicz L (2001) A leopard (Pathera pardus L. 1758) find from the Late Middle Ages in Hungary. In: Buitenhuis H, Prummel W (eds) Animals and Man in the Past, 151-160. ARC-Publicatie 41, Groningen, the Netherlands.

Bartosiewicz L (2009) A lion's share of attention: archaeozoology and the historical record. Acta Archaeologica Academiae Scientiarum Hungaricae 60: 275-289. doi:10.1556/AArch.59.2008.2.28

Bartosiewicz L, Gyetvai A, Küchelmann H-C (2010) Beast in the feast. In: Kunst G-K (ed) Bestial Mirrors. Using Animals in Reconstructing Identities in Medieval Europe. 85-99. Institute for Archaeological Science, Vienna, Austria.

Batsaikhan N, Tsytsulina K, Formozov N, Sheftel B (2008) Microtus gregalis. In: IUCN Red List of Threatened Species. Version 2014.1. http://www.iucnredlist.org. Downloaded on 21 June 2015. 
Bauer H, Nowell K, Packer C (2012) Panthera leo. In: IUCN Red List of Threatened Species. Version 2013.2. http://www.iucnredlist.org. Downloaded on 28 December 2014. Becker C (1997) Zur nacheiszeitlichen Verbreitung des Damhirsches Cervus dama in Südosteuropa - eine kritische Zwischenbilanz. In: Becker C et al. (eds) Chronos. Beiträge zur Prähistorischen Archäologie zwischen Nord- und Südosteuropa. Festschrift für B. Hänsel, 67-82. Internationale Archäologie Studia honoraria 1, Verlag Marie Leidorf, Espelkamp, Germany.

Becker C (1998) New data on the distribution of fallow deer in Europe during the late Pleistocene and Holocene. In: Buitenhuis H, Bartosiewicz L, Choyke AM (eds) Archeozoology of the Near East III. Proceedings of the Third International Symposium on the Archeozoology of Southwestern Asia and Adjacent Areas,166-171. ARC Publicates 18, Groningen, The Netherlands.

Becker C (1999) Domesticated and wild animals evidenced in the Eneolithic-Bronze Age cultures Coţofeni and Monteoru, Romania. In: Benecke N (ed) The Holocene History of the European Vertebrate Fauna, 91-108. Archäologie in Eurasien, 6. Verlag Marie Leidorf, Rahden, Germany.

Bejenaru L, Stanc S, Popvici M, Balasescu A, Cotiuga V (2013) Holocene subfossil records of the auroch (Bos primigenius) in Romania. The Holocene 23: 603-614.

Benecke N (1999) The evolution of the vertebrate fauna in the Crimean mountains from the late Pleistocene to the mid-Holocene. In: Benecke N (ed) The Holocene History of the European Vertebrate Fauna, 43-58. Archäologie in Eurasien, 6. Verlag Marie Leidorf, Rahden, Germany.

Benecke N (2005) The Holocene distribution of European bison - the archaeozoological record. Munibe (Antropologia-Arkeologia) 57: 421-428. 
Biller AZs (2013) Early Bronze Age and Roman Period elk (Alces Alces Linné, 1758) remains from the area of Budapest, Hungary. Archeometriai Mühely 10: 275-282.

Birks HJB (2005) Mind the gap: how open were European primeval forests? Trends in Ecology and Evolution 20: 154-156.

Bökönyi S (1963) Die Wirbeltierfauna der Ausgrabungen in Zalavár. In: Sós Á, Bökönyi S (eds) Zalavár, 313-371. Akadémiai Kiadó, Budapest, Hungary.

Bökönyi S (1971a) The development and history of domestic animals in Hungary. American Anthropologist 73: 640-674.

Bökönyi S (1971b) Angaben zum frühholozänen vorkommen des damhirsches, Cervus (Dama) dama (Linné, 1758), in Europa. Säugetierkundliche Mitteilungen 19: 206-217. Bökönyi S (1974) History of Domestic Mammals in Central and Eastern Europe. Akadémiai Kiadó, Budapest, Hungary.

Bökönyi S (1978) The vertebrate fauna of Vlasac. In: Serjović D, Srpsk LZ (eds) Vlasac II: $a$ Mesolithic Settlement in the Iron Gates. Akademija Nauka i Umetnosti Posebna Izd. 112. Od. Int. Nauka 5, Belgrade, Serbia.

Bölöni J, Horváth A (2012) Törpe mandula. In: Bartha D (ed) Magyarország ritka fa- és cserjefajainak atlasza, 173-177. Kossuth Kiadó, Budapest, Hungary.

Burger J, Rosendahl W, Loreille O, Hemmer H, Eriksson T, Götherström A, Hiller J, Collins MJ, Wess T, Alt KW (2004) Molecular phylogeny of the extinct cave lion Panthera leo spelaea. Molecular Phylogenetics and Evolution 30: 841-849.

Burke A, Eisenmann V, Ambler KG (2003) The systematic position of Equus hydruntinus, an extinct species of Pleistocene equid. Quaternary Research 59: 459-469.

Crutzen PJ (2002) Geology of mankind. Nature 415: 17-18.

Czier Z, Jurcsák T (1987) Un craniu de elan (Alces alces L.) descoperit in Avenul lui Avramut din Cheile Somesului Cald. Extras din Crisia 17. Oradea 611-625. 
Daróczi-Szabó M, Savanyú B (2013) Megmunkált oroszláncsontot tartalmazó gödör a középső rézkorból. Ösrégészeti Levelek 14:13-19.

Davis SJ (1980) Late Pleistocene and Holocene equid remains from Israel. Zoological Journal of the Linnean Society 70: 289-312.

Davis SJM, Mackinnon M (2009) Did the Romans bring fallow deer to Portugal? Environmental Archaeology 14:15-26.

de Bruyn M, Hoelzel AR, Carvalho GR, Hofreiter M (2011) Faunal histories from Holocene ancient DNA. Trends in Ecology \& Evolution 26: 405-413.

De Grossi Mazzorin J (1995) La fauna rinvenuta nell'area della Meta Sudans nel quadro evolutivo degli animali domestici in Italia. Padusa Quaderni 1: 309-318.

Dirzo R, Young HS, Galetti M, Ceballos G, Isaac NJB, Collen B (2014) Defaunation in the Antropocene. Science 345: 401-406.

Drucker DG, Bocherens H (2009) Carbon stable isotopes of mammal bones as tracers of canopy development and habitat use in temperate and boreal contexts. In: Creighton JD, Roney PJ (eds) Forest Canopies: Forest Production, Ecosystem Health and Climate Conditions, 103-109. Nova Science Publishers, New York, USA.

Eisenmann V, Baylac M (2000) Extant and fossil Equus (Mammalia, Perissodactyla) skulls: a morphometric definition of the subgenus Equus. Zoologica Scripta 29: 89-100.

El Susi G (1991) La fauna de l'établissement vincien de Liubcova-Orniţa (département de Caraş Severin). Banatica 11: 9-17 (in Romanian).

El Susi G (2000) Studiul resturilor faunistice din nivelul medieval de la Simleul Silvaniei'Cetate' (judetul Salaj). Arheologia Medievala 3: 267-276.

Erbajeva MA (2008) Late Pleistocene small ochotonids of Eurasia with emphasis to the history of Ochotona pusilla. In: Krempaská Z (ed) 6th Meeting of the European 
Association of Vertebrata Paleontologists, Volume of Abstracts, 38-40. The Museum of Spiš in Spišská Nová Ves, Spišská Nová Ves, Slovak Republic.

Ervynck A, Van Neer W, Lentacker A (1999) Introduction and extinction of wild animal species in historical times: the evidence from Belgium. In: Benecke N (ed) The Holocene History of the European Vertebrate Fauna, 399-408. Archäologie in Eurasien, 6. Verlag Marie Leidorf, Rahden, Germany.

Fabiš M (2003) Troia and fallow deer. In: Wagner GA, Pernicka E, Uerpmann H-P (eds) Troia and the Troad: Scientific Approaches, 263-276. Springer-Verlag, Berlin, Germany.

Feurdean A, Marinova E, Nielsen AB, Liakka J, Veres D, Hutchinson SM et al. (2015) Origin of the forest steppe and exceptional grassland diversity in Transylvania (central-eastern Europe). Journal of Biogeography 42: 951-963.

Fisher CT, Yalden DW (2004) The steppe pika Ochotona pusilla in Britain and a new northerly record. Mammal Review 34: 320-324.

Flerov KK (1979) Systematics and evolution. In: Sokolov EV (ed) European BisonMorphology, Systematics, Evolution, Ecology, 9-127. Nauka Publishers, Moscow, Russia (in Russian).

Forsten A (1993) Size decrease in Late Pleistocene-Holocene caballoid horses (genus Equus), intra- or interspecific evolution? A discussion of alternatives. Quaternary International 19: 71-75.

Forsten A (1999) A review of Equus stenonis Cocchi (Perissodactyla, Equidae) and related forms. Quaternary Science Reviews 18: 1373-1408.

Geigl E-M, Grange T (2012) Eurasian wild asses in time and space: morphological versus genetic diversity. Annals of Anatomy 194: 88-102. 
Gromova VI (1928) Der Löwe in Europa in historischer Zeit. Priroda 10: 929-930 (in Russian).

Gromova VI (1949) Istorija loshadej (roda Equus) v Starom Svete. Evoljusija I klassifikatsija roda. Vol. 2. Trudy Paleontologicheskogo Instituta Akademii Nauk SSSR 17, Moscow, Russia.

Groves CP (1994) Morphology, habitat and taxonomy. In: Boyd L, Houpt KA (eds) Przewalski's Horse: The History and Biology of an Endangered Species, 39-59. State University of New York Press, Albany, USA.

Groves CP, Grubb P (2011) Equidae. In: Groves CP, Grubb P (eds) Ungulate Taxonomy, 1317. Johns Hopkins University Press, Baltimore, USA.

Grubb P (2005) Order Perissodactyla. In: Wilson DE, Reeder DM (eds) Mammal Species of the World. A Taxonomic and Geographic Reference, Third Edition, 629-636. The John Hopkins University Press, Baltimore, USA.

Guthrie RD (2003) Rapid body size decline in Alaskan Pleistocene horses before extinction. Nature 426: 172-176.

Haimovici S (2007) Mediterranean species discovered among the animal remains from Dobrogea Province, Neolithic-Eneolitihic period. Analele Ştiinţifice ale Universităţii „Al. I. Cuza” Iaşi, s. Biologie animală 53: 291-302.

Hall SJG (2008) A comparative analysis of the habitat of the extinct aurochs and other prehistoric mammals in Britain. Ecography 31: 187-190.

Hankó B (1933) A hajdani Alföld ősi állatvilága. A Debreceni Tisza István Tudományos Társaság Honismertető Bizottságának Kiadványai 29: 1-83.

Henschel P, Hunter L, Breitenmoser U, Purchase N, Packer C, Khorozyan I, Bauer H, Marker L, Sogbohossou E, Breitenmoser-Wursten C (2008) Panthera pardus. In: IUCN Red 
List of Threatened Species. Version 2013.2. http://www.iucnredlist.org. Downloaded on 28 December 2014.

Hewitt GM (2002) The genetic legacy of the Quaternary ice ages. Nature 405: 907-913.

Horváth R, Magura T, Szinetár Cs, Tóthmérész B (2009) Spiders are not less diverse in small and isolated grasslands, but less diverse in overgrazed grasslands: a field study (East Hungary, Nyírség). Agriculture, Ecosystems and Environment 130: 16-22.

Illyés E, Bölöni J, Kovács G, Kállyané Szerényi J (2007) Importance, distribution and site conditions of dry grasslands in Hungary. In: Illyés E, Bölöni J (eds) Slope Steppes, Loess Steppes and Forest Steppe Meadows in Hungary, 164-169. MTA ÖBKI, Budapest, Hungary.

Jánossy D (1976) Die Revision jungmittelpleistozäner Vertebratenfaunen in Ungarn. Fragmenta Mineralogica et Palaeontologica 7: 29-54.

Jánossy D, Vörös I (1981) Pleistozäner Skelettfund des Ures (Bos primigenius Bojanus) von Nagybajom (Ungarn). Fragmenta Mineralogica et Palaeontologica 10: 79-96.

Jurcsák T (1974) Galoşpetreu, Vadu Crişului. In: Repertoriul Monumentelor Naturii, arheologice, istorice, etnografice, de arhitectură şi artă din judeţul Bihor. Oradea, Romania.

Kahlke RD (1999) The History of the Origin, Evolution and Dispersal of the Late Pleistocene Mammuthus-Coelodonta Faunal Complex in Eurasia (Large Mammals). Fenske Companies, Rapid City, South Dakota, USA.

Katzner TE, Bragin EA, Knick ST, Smith AT (2005) Relationship between demographics and diet specificity of imperial eagles Aquila heliaca in Kazakhstan. Ibis 147: 576-586.

Kerley GIH, Kowalczyk R, Cromsigt JPGM (2012) Conservation implications of the refugee species concept and the European bison: king of the forest or refugee in a marginal habitat? Ecography 35: 519-529. 
Koch A (1888) Új adatok a Kolozsvár vidéki diluvialis fauna ismeretéhez. OrvosTermészettudományi Értesitő 13: 13-18.

Kordos L (1978) A sketch of the Vertebrata Biostratigraphy of the Hungarian Holocene Földrajzi Közlemények 101/25: 144-160.

Kordos L (1981) A magyarországi holocén képzödmények gerinces-faunafejlödése, biosztratigráfiája és paleoökológiája. DSc Thesis, Budapest, Hungary.

Kosintcev PA (1999) Formation and evolution of the Holocene fauna of the megamammals in the Urals and West Siberia. In: Benecke N (ed) The Holocene History of the European Vertebrate Fauna, 133-140. Archäologie in Eurasien, 6. Verlag Marie Leidorf, Rahden, Germany.

Krasińka M, Krasińki ZA (2013) European bison - the nature monograph. Springer-Verlag, Berlin, Heidelberg, Germany. doi:10.1007/978-3-642-36555-3.

Kretzoi M (1946) On Bison bonasus hungarorum n. ssp. Annales Historico-Naturales Musei Nationalis Hungarici 39: 105-111.

Kretzoi M (1954) Mormota-maradványok Debrecenből. Földtani Közlöny 84: 75-77.

Kretzoi M (1968) Étude paléontologique. In: Gábori M, Csánk V (eds) La station du paléolithique moyen d'Éra, Hongrie, 59-104. Budapest, Hungary.

Lai CH, Smith AT (2003) Keystone status of plateau pikas (Ochotona curzoniae): effect of control on biodiversity of native birds. Biodiversity and Conservation 12: 1901-1912.

Lorenzen ED, Nogués-Bravo D, Orlando L, Weinstock J, Binladen J, Marske KA et al. (2011) Species-specific responses of Late Quaternary megafauna to climate and humans. Nature 479: 359-365.

Ludwig A, Pruvost M, Reissmann M, Benecke N, Brockmann GA, Castaños P et al. (2009) Coat color variation at the beginning of horse domestication. Science 324: 485. 
Magyari EK, Chapman JC, Passmore DG, Allen JRM, Huntley JP, Huntley B (2010) Holocene persistence of wooded steppe in the Great Hungarian Plain. Journal of Biogeography 37: 915-935.

Malez M (1972) Ostaci fosilnog čovjeka iz gornjeg pleistocena Šandalje kod Pule (Istra). Palaeontologia Jugoslavica 12: 5-39.

Martin PS, Steadman DW (1999) Prehistoric extinctions on islands and continents. In: MacPhee RDE (ed) Extinctions in Near Time: Causes, Contexts and Consequences, $17-$ 55. Kluwer Academic/Plenum, New York, USA.

Masseti M, Mertzanidou D (2008) Dama dama. In: IUCN Red List of Threatened Species. Version 2013.2. http://www.iucnredlist.org. Downloaded on 21 January 2015. Moores EM, Fairbridge RW (1997) Encyclopedia of European and Asian Regional Geology. Springer Verlag, Berlin, Germany.

Mottl M (1936) A bervavölgyi sziklaüreg állatvilága, különös tekintettel a hazai magdalénienre. Földtani Közlöny 46: 1-10.

Murdoch JD, Munkhzul T, Buyandelger S, Reading RP, Sillero-Zubiri C (2009) The Endangered Siberian marmot Marmota sibirica as a keystone species? Observations and implications of burrow use by corsac foxes Vulpes corsac in Mongolia. Oryx 43: 431434.

Niu Y, Wei F, Li M, Liu X, Feng Z (2004) Phylogeny of pikas (Lagomorpha, Ochotona) inferred from mitochondrial cytochrome $b$ sequences. Folia Zoologica 53: 141-155.

Orlando L, Mashkour M, Burke A, Douady CJ, Eisenmann V, Hänni C (2006) Geographic distribution of an extinct equid (Equus hydruntinus: Mammalia, Equidae) revealed by morphological and genetical analyses of fossils. Molecular Ecology 15: 2083-2093.

Outram AK, Stear NA, Bradrey R, Olsen S, Kaparov A, Zaibert V et al. (2009) The earliest horse harnessing and milking. Science 323: 1332-1335. 
Pazonyi P (2011) Paleoecology of Late Pleistocene and Quaternary mammalian communities in the Carpathian Basin. Acta zoologica cracoviensia 54A: 1-29.

Pazonyi P, Kordos L, Magyari E, Marinova E, Fűköh L, Venczel M (2014) Pleistocene vertebrate faunas of the Süttő Travertine Complex (Hungary). Quaternary International 319: 50-63.

Ponomarev D, Puzachenko A, Bachura O, Kosintsev P, Plicht J (2013) Mammal fauna during the Late Pleistocene and Holocene in the far northeast of Europe. Boreas 42: 779-797.

Pruvost M, Bellone R, Benecke N, Sandoval-Castellanos E, Cieslak M, Kuznetsova T et al. (2011) Genotypes of predomestic horses match phenotypes painted in Paleolithic works of cave art. Proceedings of the National Academy of Sciences 108: 18626-18630.

Pushkina D, Raia P (2008) Human influence on distribution and extinctions of the late Pleistocene Eurasian megafauna. Journal of Human Evolution 54: 769-782.

Rabiei A, Saltz D (2011) Dama mesopotamica. In: IUCN Red List of Threatened Species. Version 2013.2. http://www.iucnredlist.org. Downloaded on 21 January 2015.

Rakovec I (1956) The remnants of the elk (Alces alces L.) in Yugoslavia. Geološki anali Balkanskoga poluostrva 24: 1-14.

Raup DM (1994) The role of extinction in evolution. Proceedings of the National Academy of Sciences 91: 6758-6763.

Schmitt T (2007) Molecular biogeography of Europe: Pleistocene cycles and postglacial trends. Frontiers in Zoology 4: 11. doi:10.1186/1742-9994-4-11

Schmitzberger (2009) Haus- und Jagdtiere im Neolithikum des österreichischen Donauraumes. $\mathrm{PhD}$ thesis, Universität Wien, Vienna, Austria.

Schmölcke U, Zachos FE (2005) Holocene distribution and extinction of the moose (Alces alces, Cervidae) in Central Europe Mammalian Biology 70: 329-344. 
Schwartz ChA (1998) Eastern Hungary: animal bones from Polgár-Csőszhalom. In: Antreiter P, Bartosiewicz L, Jerem E, Meid W (eds.) Man and the Animal World: Studies in Archeozoology, Archeology, Anthropology and Palaeolinguistics in Memoriam Sándor Bökönyi, 511-514. Archeolingua, Budapest, Hungary.

Smirnov NG (1993) Small Mammals of the Middle Urals in Upper Pleistocene and Holocene. Nauka, Yekaterinburg, Russia (in Russian).

Smith AT (1994) The last pikas and the last steppes in Europe. Species 23: 68-69.

Smith AT, Johnston CH (2008) Ochotona pusilla. In: IUCN Red List of Threatened Species. Version 2012.2. http://www.iucnredlist.org. Downloaded on 03 March 2015.

Sokolov II (1967) Przewalski horse. Short review of discovery and study in the Soviet Union. Byulleten Moskovskogo Obshtchestva Ospytateley Prirody, Otdelek Biologii 72: 99-113 (in Russian).

Sommer R, Benecke N (2006) Late Pleistocene and Holocene development of the felid fauna (Felidae) of Europe: a review. Journal of Zoology 269: 7-19.

Sommer RS, Benecke N, Lõugas L, Nelle O, Schmölcke U (2011) Holocene survival of the wild horse in Europe: a matter of open landscape? Journal of Quaternary Science 26: $805-812$

Sommer R, Kalbe J, Ekström J, Benecke N, Liljegren R (2014) Range dynamics of the reindeer in Europe during the last 25,000 years. Journal of Biogeography 41: 298-306. Sommer RS, Nadachowski A (2006) Glacial refugia of mammals in Europe: evidence from fossil records. Mammal Review 36: 251-265.

Steffen W, Grinevald J, Crutzen PJ, McNeill JR (2011) The Anthropocene: conceptual and historical perspectives. Philosophical Transactions of the Royal Society A 369: 842-867. 
Street M, Baales M, Cziesla E, Hartz S, Heinen M, Jöris O, Koch I, Pasda C, Therberger T, Vollbreht J (2002) Final Paleolithic and Mesolithic research in reunified Germany. Journal of World Prehistory 15: 365-453.

Sykes N, Carden RF, Harris K (2013) Changes in the size and shape of fallow deer-evidence for the movement and management of a species. International Journal of Osteoarchaeology 23: 55-68.

Symeonidis N, Bachmayer F, Zapfe H (1980) Ergebnisse weiterer Grabungen in der Höhle von Vraona (Attika, Griechenland). Annales Gaeologiques des Pays Hellaeniques Athaenes 30: 291-299.

Szalay B (1916) Jávorszarvasunk. A magyarországi Alces palmatus története. Vadászlap 37: $1-11$.

Topál Gy, Vörös I (1984) Notes on history and recent records of elk (Alces alces [L.]) in Hungary. Vertebrata Hungarica 22: 83-94.

Turvey ST, Fritz SA (2011) The ghosts of mammals past: biological and geographical patterns of global mammalian extinction across the Holocene. Philosophical Transactions of the Royal Society B 366: 2564-2576.

van Vuure C (2005) Retracing the Aurochs: History, Morphology and Ecology of an Extinct Wild Ox. Pensoft, Sofia-Moscow, Russia.

Varga Z (1995) Geographical patterns of biological diversity in the Palaearctic Region and the Carpathian Basin. Acta Zoologica Academiae Scientiarum Hungaricae 41: 71-92. Venczel M (2000) Quaternary Snakes from Bihor (Romania). Publishing House of the Țării Crişurilor Museum, Oradea, Romania.

Vera FWM (2000) Grazing Ecology and Forest History. CAB International, Wallingford, UK. 
Vera FWM, Bakker ES, Olff H (2006) Large herbivores: missing partners of western European light-demanding tree and shrub species? In: Danell K, Duncan P, Bergström R, Pastor J (eds) Large Herbivore Ecology, Ecosystem Dynamics and Conservation, 203-231. Cambridge University Press, Cambridge, UK.

Verkaar ELC, Nijman IJ, Beeke M, Hanekamp E, Lenstra JA (2004) Maternal and paternal lineages in cross-breeding bovine species. Has wisent a hybrid origin? Molecular Biology and Evolution 21: 1165-1170.

Vigne J-D (1999) The large "true" Mediterranean islands as a model for the Holocene human impact on the European vertebrate fauna? Recent data and new reflections. In: Benecke N (ed) The Holocene History of the European Vertebrate Fauna, 295-322. Archäologie in Eurasien, 6. Verlag Marie Leidorf, Rahden, Germany.

Visy Zs (ed; 2003) Magyar régészet az ezeredfordulón. Hungarian Ministry of Cultural Heritage, László Teleki Foundation, Budapest, Hungary.

Vlasakker J van de (2014) Bison Rewilding Plan, 2014-2024. Rewilding Europe's contribution to the comeback of the European bison. Rewilding Europe, Nijmegen, The Netherlands.

von Koenigswald W (2002) Lebendige Eiszeit. Klima und Tierwelt im Wandel. TheissWissenschaftliche Buchgemeinschaft, Darmstadt, Germany.

Vörös I (1981) Wild equids from the Early Holocene in the Carpathian Basin. Folia Archaeologica 32: 37-68.

Vörös I (1983) Lion remains from the Late Neolithic and Copper Age of the Carpathian Basin. Folia Archaeologica 34: 33-50.

Vörös I (1985) Early Medieval aurochs (Bos primigenius Boj.) and his extinction in Hungary. Folia Archaeologica 36: 193-221. 
Vörös I (1987a) Large mammal faunal changes during the Late Upper Pleistocene and Early Holocene times in the Carpathian Basin. In Pécsi M (ed.) Pleistocene Environment in Hungary. Geographical Research Institute, Hungarian Academy of Science, Budapest, Hungary.

Vörös I (1987b) A tiszalúc-sarkadi rézkori település állatcsontleletei. [Animal remains from the Copper Age settlement of Tiszalúc-Sarkad.] Folia Archaeologica 38: 121-126.

Vörös I (1987c) An aurochs (Bos primigenius Boj.) skeleton from the Mesolithic peat-bogs at Kecel-Rózsaberek. Folia Archaeologica 38: 65-88.

Vörös I (1994) Animal husbandry and hunting in the Middle Neolithic settlement at Tiszavasvári-Deákhalmi-dűlő (Upper Tisza region). Jósa András Múzeum Évkönyve 36: 167-184.

Vörös I (2000) Hunted mammals from the Gravettian campsite Bodrogkeresztúr-Henye (NE Hungary). In: Dobosi VT (ed) Bodrogkeresztúr-Henye (NE Hungary) Upper Palaeolithic Site, 113-212. Magyar Nemzeti Múzeum, Budapest, Hungary. Vörös I (2003) Vadászott állatok. In: Visy Zs (ed) Magyar régészet az ezredfordulón. Hungarian Ministry of Cultural Heritage, László Teleki Foundation, Budapest. Vörös I (2005) Neolithic animal husbandry and hunting in the Great Hungarian Plain. Hétköznapok Vénuszai. Hódmezővásárhely 2005: 203-243 (in Hungarian with English summary).

Vörös I (2012) Balatonöszöd késő rézkori településén feltárt emlősállatok maradványai.

[Excavated mammal remains from a Late Copper Age settlement in Balatonöszöd.] In: Horváth T (ed.) Balatonöszöd-Temetöi-dülő öskori településrészei, 277-338. MTA BTK Régészeti Intézet, Budapest, Hungary. 
Vörös I (2013) Adatok az Árpád-kori vadászat történetéhez. (Angaben zur Geschichte der Árpádenzeitlichen Jagd.) Folia Archaeologica 55: 217-262 (in Hungarian with German summary).

Walker M, Johnsen S, Rasmussen SO, Popp T, Steffensen J-P, Gibbard P et al. (2009) Formal definition and dating of the GSSP (Global Stratotype Section and Point) for the base of the Holocene using the Greenland NGRIP ice core, and selected auxiliary records. Journal of Quaternary Science 24: 3-17.

Walker MJC, Berkelhammer M, Björck S, Cwynar LC, Fisher DA, Long AJ, Lowe JJ, Newnham RM, Rasmussen SO, Weiss H (2012) Formal subdivision of the Holocene Series/Epoch: A discussion paper by a working group of INTIMATE (integration of icecore, marine and terrestrial records) and the subcommission on Quaternary stratigraphy (International Commission on Stratigraphy). Journal of Quaternary Science 27: 649659.

Wroe S, Field J, Fullagar R, Jermiin L (2004) Late Quaternary extinctions of megafauna and the global overkill hypothesis. Alcheringa 28: 291-331.

Zhuralev OP (1999) Säugetierfauna und Umwelt am Südlichen Bug während der Antike. In: Benecke N (ed) The Holocene History of the European Vertebrate Fauna, 389-398. Archäologie in Eurasien, 6. Verlag Marie Leidorf, Rahden, Germany. 


\section{Figure legends}

Fig. 1. Holocene temporal range and disappearance of mammal species in the Carpathian Basin. Solid black lines indicate dated subfossil finds from palaeontological or archaeozoological sources, grey lines represent historical data, and dotted line shows the assumed presence of species.

Species (size of silhouette not to scale): A: steppe pika, B: narrow-headed vole, C: bobak marmot, D: lion, E: leopard, F: wild horse, G: Asiatic wild ass, H: European fallow deer, I: Eurasian elk, J: aurochs, K: European bison. Abbreviations: E: Early, M: Middle, L: Late, R: Roman Age, M.p.: Migratory period, Á.d.: Árpád dynasty. BC/AD: before Christ/anno Domini, cal. yr. BP: calendar years before present. Early Iron Age and Modern Age are not labelled on the timeline. For references to climatic phases and cultural epochs, see text.

Fig. 2. Spatial distribution of known occurrences of extinct Holocene mammal species in the Carpathian Basin. Maps A-D and G-K: solid triangles show localities of subfossil finds, unfilled triangles show historical data, and white triangles show occurrences relevant to the present study but geographically outside of or on the edge of the Carpathian Basin. On map F, unfilled triangles denote Copper Age archaeozoological records. There is no Map E, as no records are available for the leopard. Map labels refer to the species as in Fig 1. The inset map shows the position of the Carpathian Basin within Europe. 
Fig. 1

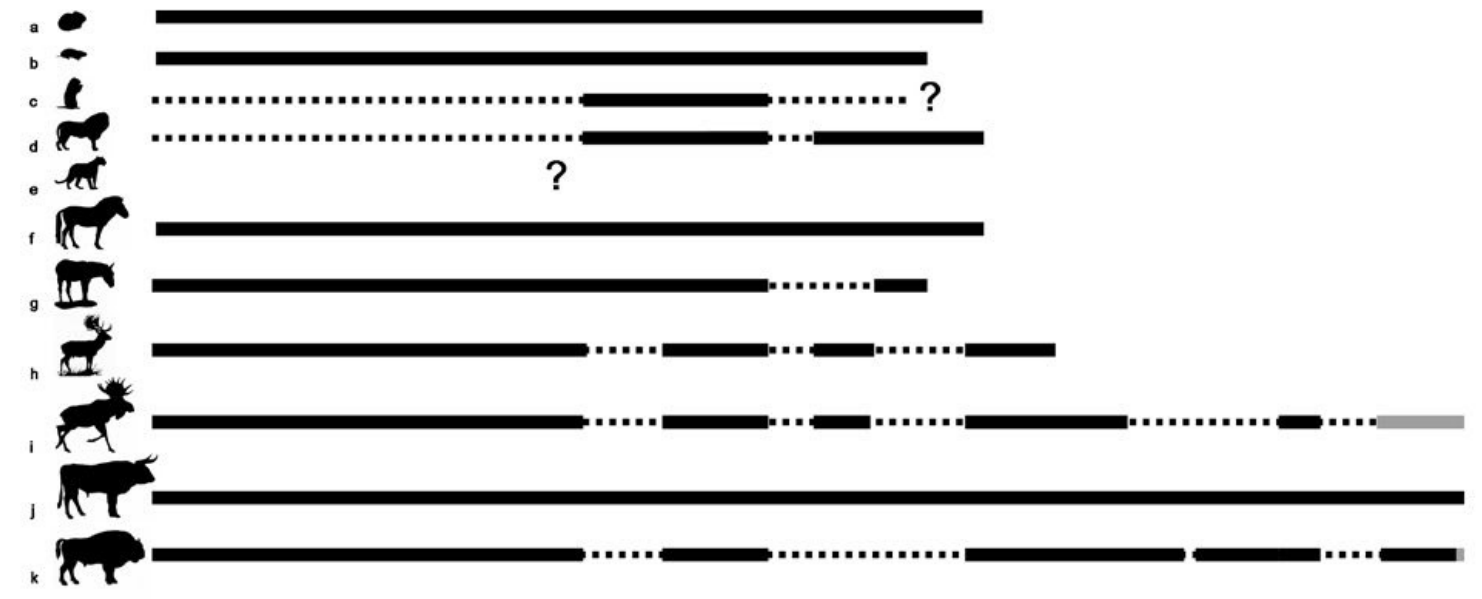




Fig. 2

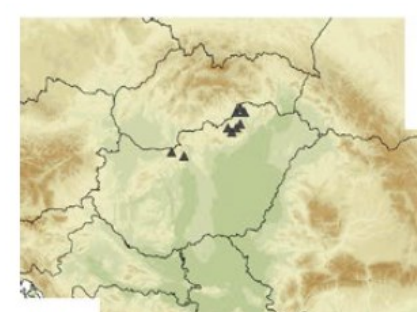

(a)
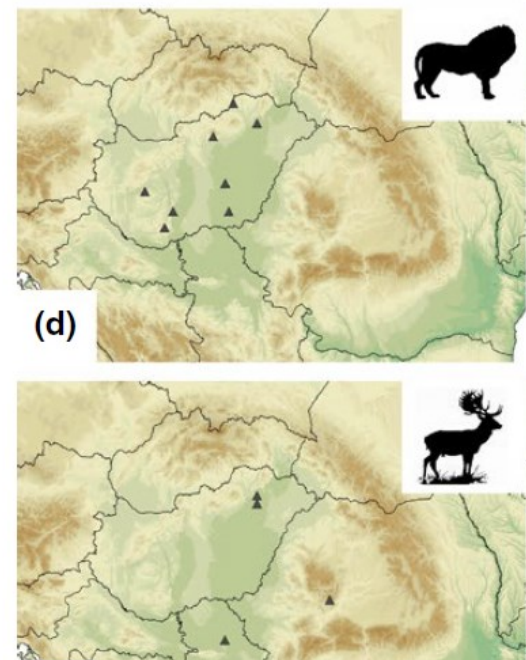

(h)

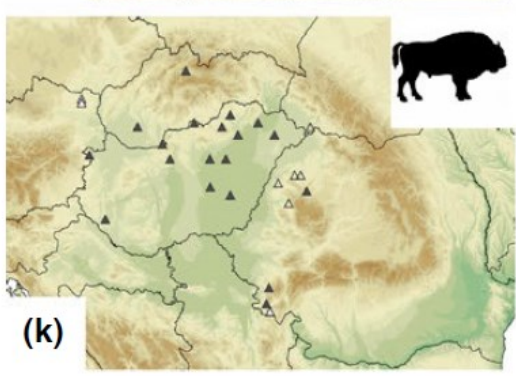

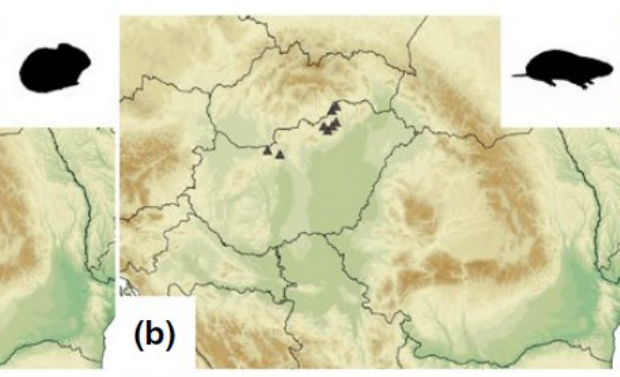
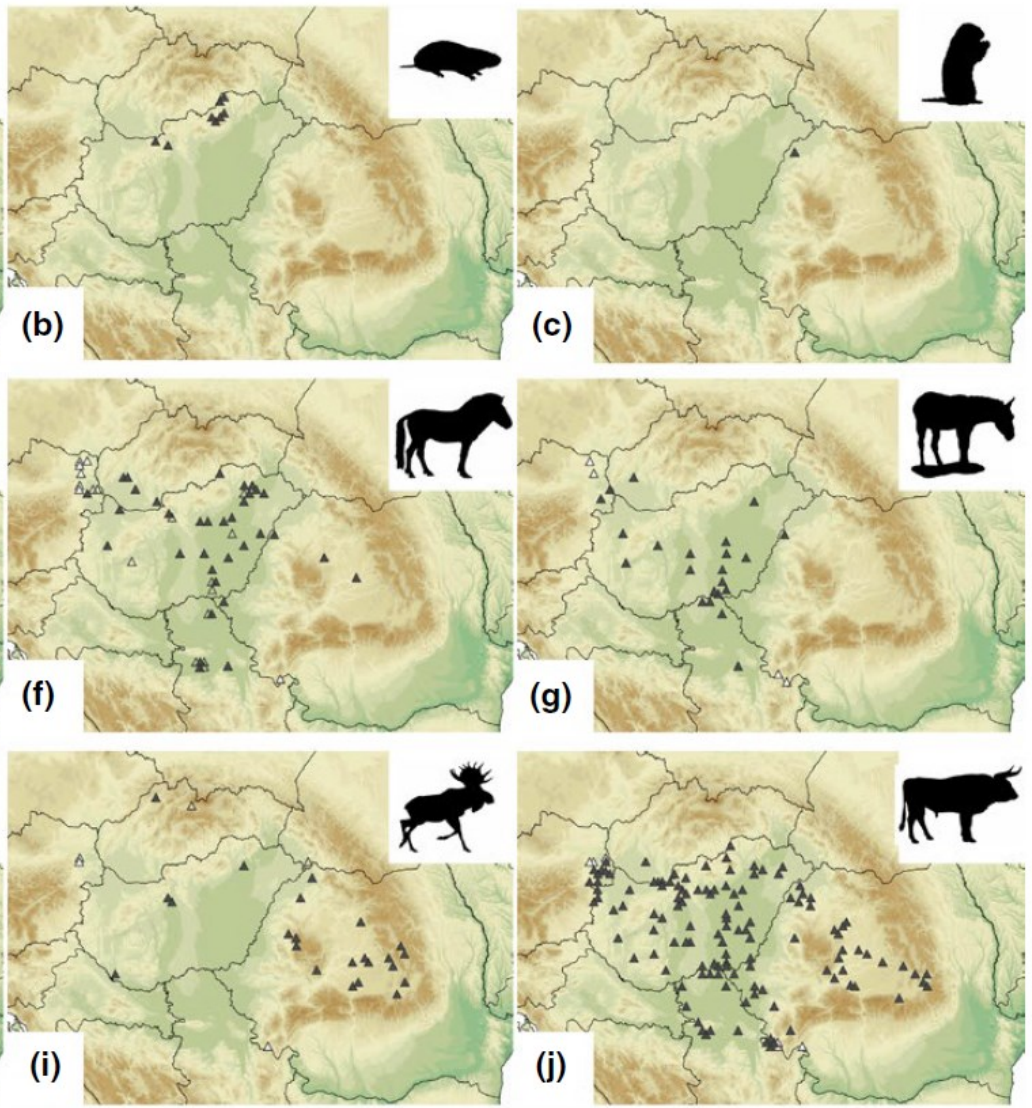

(i)

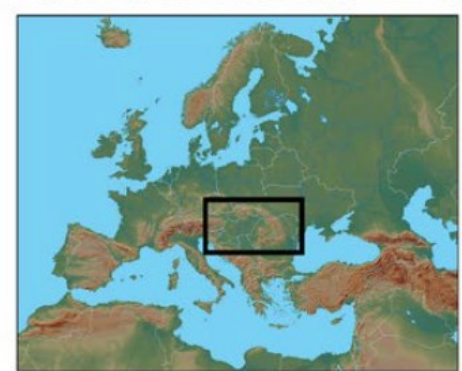

